\title{
The Role of Anti-Helicobacter Pylori Therapy in Remission Induction of Primary Gastric Lymphoma by Analysis of Microsatellite Instability
}

\author{
${ }^{1}$ Clinical pathology department, Assuit University, Egypt \\ ${ }^{2}$ Internal Medicine department, Gastroenterology and endoscopy unit, Assuit, Egypt \\ ${ }^{3}$ Medical Oncology department South Egypt Cancer Institute, Egypt \\ ${ }^{4}$ Medical Oncology department, National cancer Institute, Cairo, Egypt \\ ${ }^{5}$ Oncology Department, Assiut University, Egypt
}

Azza M Ezz Eldin ${ }^{1 *}$, Enas Reda Alkareemy², Ashraf Zedan ${ }^{3}$, Ahmed Abdel Warith $^{4}$, Amen H. Zaky $^{3}$ and A Khalifa ${ }^{5}$

\begin{abstract}
Background: The molecular mechanism associated with remission of primary gastric lymphoma post helicobacter pylori eradication is still unclear.

Aim of the study: to evaluate Microsatellite (MSI) instability at markers adjacent to Chromosomal loci involved in primary gastric lymphoma in relation to helicobacter eradication therapy.

Methods: 107 primary gastric lymphoma patients included 30 low grade Mucosa Associated Lymphoid Tissue Gastric lymphoma (MALT), 36 Diffuse large gastric lymphoma with MALT component (MALTDLBCL) and 41 DLBCL gastric lymphoma (DLBCL) were treated with anti Helicobacter pylori therapy as first line treatment and to asses for Microsatellite instability (MSI)

Results: the incidence of complete remission post helicobacter pylori eradication was higher in Low grade MALT in comparison to MALTDLBCL and denovo DLBCL. The incidence of MSI is decrease post helicobacter pylori eradication in all subtypes level.

Conclusion: Remission of gastric lymphoma post Helicobacter eradication may associate with correction of MSI
\end{abstract}

Keywords: Gastric lymphoma; Microsatellite instability; Helicobacter pylori

\section{Introduction}

Non-Hodgkin's Lymphoma of the stomach is the most common group of primary extra-nodal lymphomas [1]. Primary gastric lymphoma represents $5 \%$ of gastric malignancy and shows increasing incidence worldwide [2]. The majority of primary gastric lymphoma are of a B-cell type, representing either as a low-grade disease of Mucosa-Associated Lymphoid Tissue (MALT) subtype or as a more aggressive Diffuse Large B-Cell Lymphoma (DLBCL) [3], the diffuse lymphoma can arise as a de novo tumor or through transformation from a low grade MALT (MALTDLBCL) [4].

Helicobacter Pylori infection is known to be linked to the development of MALT of the stomach [5]. It triggers a chronic antigenic stimulus that would initiate the development of gastric MALT along a continuum pathway, and ultimately might lead to a high-grade tumor, this acquires an autonomous growth potential through progressive accumulation of genetic changes $[6,10,11]$. Helicobacter pylori positive infection is observed in 35\% of DLBCL of stomach but is found more commonly in cases with concomitant MALT areas than in de novo $[7,8,12]$

Eradication of Helicobacter pylori is a well-recognized initial approach to treatment of low-grade gastric MALT lymphomas.

Several studies have shown that Helicobacter pylori eradication lead to a durable histological complete remission in patients with gastric DLBCL (with and without MALT Component) [9-16]. The molecular mechanism of regression of primary gastric lymphoma after helicobacter pylori eradication is still unknown.
Certain genetic aberration were found to be associated with gastric MALT lymphoma including trisomy 3 , trisomy 5 , trisomy $18, \mathrm{t}$ $[11,18](\mathrm{q} 21, \mathrm{q} 21)$ as well as mutation in p53 and p16 which are linked to DLBCL $[3,17,18]$.

Microsatellites are short repeat sequences dispersed throughout the genome. Defects in the DNA repair are reflected by DNA microsatellite instability [18]. Microsatellite instability is used to identify genetic loci that have been lost to detect genomic alterations and to evaluate the contribution of the mutator pathway to the gastric lymphoma pathogenesis $[3,18]$. The involvement of microsatellite instability in the pathogenesis of gastric lymphoma is controversial [17,19-21]. Many reports have demonstrated that microsatellite instability has more prominent role in the pathogenesis of gastric MALT lymphoma when microsatellite instability analyzed with markers adjacent to chromosomal loci that are involved in lymphomas, 'Real Common Target genes theory'[3,18].

We aimed in this study to evaluate Microsatellite instability (MSI)

*Corresponding author: M Ezz Eldin, Egypt, Clinical pathology department, Assiut University Egypt, Tel: 0020101918207; E-mail: Azzam80@hotmail.com

Received October 04, 2010; Accepted October 29, 2010; Published October 29, 2010

Citation: Ezz Eldin AM, Alkareemy ER, Zedan A, Abdel Warith A, Zaky AH, et al. (2010) The Role of Anti-Helicobacter Pylori Therapy in Remission Induction of Primary Gastric Lymphoma by Analysis of Microsatellite Instability. J Carcinogene Mutagene 1:107. doi:10.4172/2157-2518.1000107

Copyright: (c) 2010 Ezz Eldin AM, et al. This is an open-access article distributed under the terms of the Creative Commons Attribution License, which permits unrestricted use, distribution, and reproduction in any medium, provided the original author and source are credited. 
Citation: Ezz Eldin AM, Alkareemy ER, Zedan A, Abdel Warith A, Zaky AH, et al. (2010) The Role of Anti-Helicobacter Pylori Therapy in Remission Induction of Primary Gastric Lymphoma by Analysis of Microsatellite Instability. J Carcinogene Mutagene 1:107. doi:10.4172/2157-2518.1000107

Page 2 of 5

at microsatellite markers adjacent to loci involved in primary gastric lymphoma in relation to helicobacter eradication therapy.

\section{Materials and Methods}

One hundred-seven (107) patients with B-cell primary extra-nodal gastric Non-Hodgkin lymphoma were included in this study. None of them had received chemotherapy therapy or $\mathrm{H}$ pylori eradication before enrollment to this study, all of them had a negative family history suggestive of hereditary non-polyposis colorectal cancer. Written informed consent was obtained from patients before being interviewed for this study. The diagnosis was established according to the criteria of the WHO Classification by morphological and immunophenotypic analyses [4].

Staging work-up included detailed The diagnostic work-up included patients' history and physical examination, routine laboratory investigations (such as lactate dehydrogenase lupper range, 240 $\mathrm{U} / \mathrm{L}$, liver enzymes, alkaline phosphatase, creatinine, serum protein electrophoresis, immune globulins, and RBCs and WBCs count), chest $\mathrm{x}$-ray, radiologic and endoscopic evaluation with multiple biopsies of the upper and lower GI tract, computed tomography of chest and abdomen and pelvis, bone marrow aspiration \& biopsy, and an examination of Waldeyer's ring, small-bowel series, barium enema study of the colon and rectum, and biopsy. Patients were staged according to Musshoff's modification of the Ann Arbor staging system [22]. All patients were positive for Helicobacter pylori, as assessed by rapid urease test, bacterial culture and Warthin-Starry silver staining of gastric biopsy specimens (four biopsy specimens obtained to assess $H$. pylori infection, two from the greater curvature of the antrum and the others from the greater curvature of the corpus. H. pylori status was determined to be present by a positive result of both WarthinStarry staining and $H$. pylori culture).

All patients consented to a Helicobacter Pylori eradication therapy consisted of amoxicillin $500 \mathrm{mg}$ qid, clarithromycin $500 \mathrm{mg}$ bid, plus omeprazole $20 \mathrm{mg}$ bid for 2 weeks.

Patients were scheduled for first follow-up upper gastrointestinal endoscopic examination 4 weeks after completion of antimicrobial therapy, and follow-up repeated every 6 weeks until histological evidence of remission achieved. Complete histological remission was defined according to Wotherspoon's score of 2 or less on every histological section of the biopsy specimens [23]. In patients with grossly stable or progressive disease on follow-up endoscopic examination and in patients with a persistent or increasing proportion of large cells on microscopic examination, was referred immediately to systemic chemotherapy (CHOP). Patients received 2 cycles after achieving CR, minimum 6 cycles in total.

\section{Genomic DNA extraction}

Specimens were fixed in $10 \%$ formalin and embedded in paraffin wax, and $4-\mu \mathrm{m}$ consecutive sections were used for histological examination by H\&E staining. From the paraffin embedded blocks, two $7-\mu \mathrm{m}$ tissue sections were cut. DNA was extracted from the malignant lymphoma area and from normal mucosa of the stomach. The DNA extraction procedure, tissue was precisely microdissected under microscopic visualization using a PixCell-II Laser Capture Microdissection System to avoid DNA contamination of inflammatory or stromal cell nuclei, as previously reported [24,25].

\section{Microsatellite marker analysis}

As reported previously, microsatellite instability analyzed with micro satellite markers adjacent to chromosomal loci that are involved in lymphomas [3,18] as follows: D3S1530 (3q27), D5S346 (5q21), D9S171 (9p21), D17S250 (17p12), D18S474 (18q21). One primer for each primer pair was fluorescence-labeled at the 5' end ( FAM, TAMARA, NED, ROX and HEX). Multiplex PCR amplification was carried out in a reaction volume of $10 \mu \mathrm{L}$, which contained 100 ng of genomic DNA, 1X PCR buffer (Perkin Elmer Applied Biosystems Division, Foster City, CA), $200 \mu \mathrm{mol} / \mathrm{L}$ of each dNTP, $600 \mu \mathrm{mol} / \mathrm{L}$ of each primer, and 1.5 units of AmpliTaq GOLD polymerase (Perkin Elmer). The $\mathrm{MgCl}_{2}$ concentration was $1.5 \mathrm{mmol} / \mathrm{L}$. The following PCR cycle conditions were used for amplification: $95^{\circ} \mathrm{C}$ for $10 \mathrm{~min}, 30$ cycles of $95^{\circ} \mathrm{C}$ for $45 \mathrm{sec}, 55^{\circ} \mathrm{C}$ for $1 \mathrm{~min}$ and $72^{\circ} \mathrm{C}$ for $30 \mathrm{sec}$. PCR products were evaluated for MSI by capillary electrophoresis using an ABI prism 310 Genetic analyzer (Perkin Elmer) and automatic sizing of the alleles using a Gene Scan (Applied Biosystems).

Microsatellite instability was defined as a change of length due to either insertion or deletion of repeating units in a microsatellite within tumor cells as compared to normal cells $[26,27]$. The change presented as novel peaks in tumor tissue differing in size and location from normal tissue DNA (Figure 1)

Tumors defined microsatellite instable when observed in more than $30 \%$ of examined loci $[26,27]$. In the literature, the MSI phenotype categorized into two groups: MSI-H and MSI-L/MSS, and a sample is defined as MSI only when MSI-H was observed.

\section{Statistical analysis}

Comparison of discrete variables was performed by chi-square test or Fisher's exact test. All statistical tests were two-sided, and a P value of less than .05 considered statistically significant.

\section{Results}

A total of 107 eligible patients were studied, 30 patients (28\%) had low grade MALT gastric lymphoma, 36 patients (34\%) had high grade gastric DLBCL with MALT component (MALTDLBCL), and 41 patients (38\%) had de novo DLBCL gastric lymphoma.

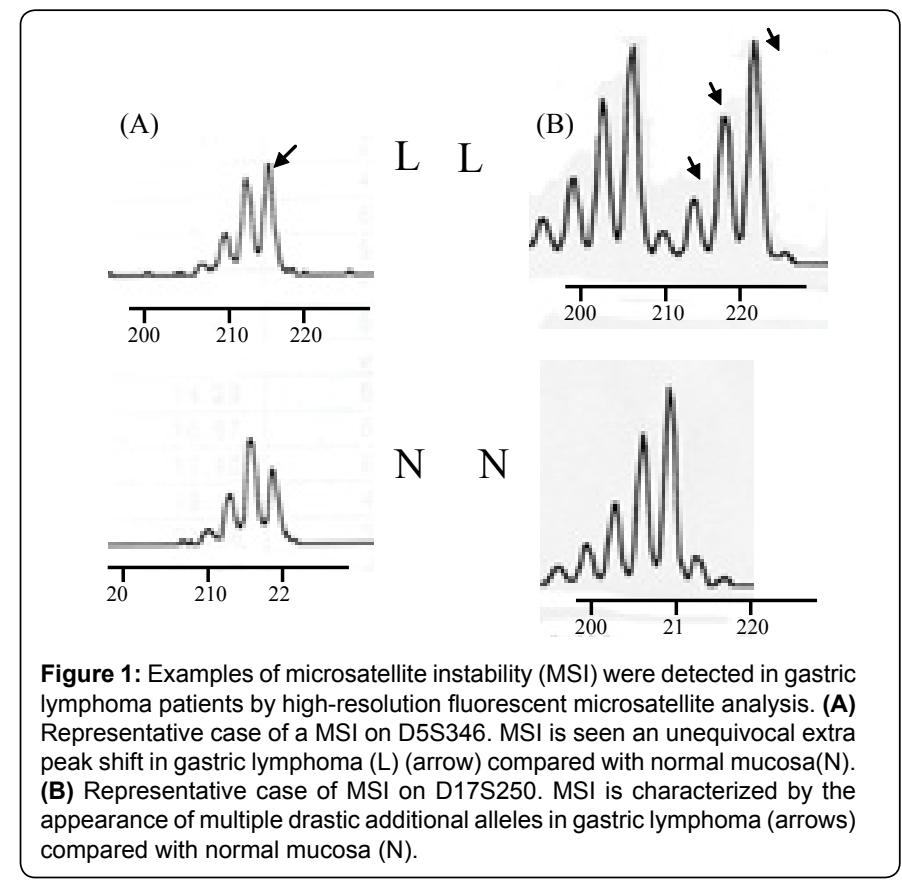




\begin{tabular}{|c|c|c|c|}
\hline & $\begin{array}{l}\text { Low grade } \\
\text { MALT }\end{array}$ & MALT DLBCL & \begin{tabular}{|l} 
De Novo \\
DLBCL
\end{tabular} \\
\hline Number & 30 & 36 & 41 \\
\hline Male/female & $10 / 20$ & $25 / 11^{a^{*}}$ & $30 / 11^{\mathrm{b} \#}$ \\
\hline $\begin{array}{l}\text { Mean age, } \\
\text { Year (range) }\end{array}$ & $\begin{array}{l}59 \\
(38-85)\end{array}$ & $\begin{array}{l}60.7 \\
(45-77)\end{array}$ & $\begin{array}{l}67.4^{\mathrm{b} \$} \\
(44-85)\end{array}$ \\
\hline \multicolumn{4}{|l|}{ Tumor site } \\
\hline $\begin{array}{l}\text { Proximal } \\
\text { Middle } \\
\text { Distal } \\
\text { Diffuse } \\
\end{array}$ & $\begin{array}{l}6(20 \%) \\
14(47 \%) \\
10(33 \%) \\
0(0 \%) \\
\end{array}$ & $\begin{array}{c}10(28 \%) \\
11(0 \%) \\
10(28 \%) \\
5(14 \%) \\
\end{array}$ & $\begin{array}{l}10(24 \%) \\
12(30 \%) \\
14(34 \%) \\
5(12 \%) \\
\end{array}$ \\
\hline \multicolumn{4}{|l|}{ Enoscopic appearance } \\
\hline $\begin{array}{l}\text { Ulcer } \\
\text { Erosion +giant fold } \\
\text { Atypical mucosa } \\
\text { Bulky mass }\end{array}$ & $\begin{array}{l}17(42 \%) \\
9(26 \%) \\
4(18 \%) \\
0(0 \%)\end{array}$ & $\begin{array}{l}13(36 \%) \\
7(20 \%) \\
8(22 \%) \\
8(22 \%) \\
\end{array}$ & $\begin{array}{l}15(36 \%) \\
6(15 \%) \\
7(17 \%) \\
14(34 \%) \\
\end{array}$ \\
\hline \multicolumn{4}{|l|}{ Tumor invasion } \\
\hline $\begin{array}{l}\text { Mucosa+Submucosa } \\
\text { Muscularispropria+subserosa }\end{array}$ & $\begin{array}{|ll|}27 & (90 \%) \\
3 & (10 \%) \\
\end{array}$ & $\begin{array}{ll}23 \text { as } & (64 \%) \\
13^{\text {cs }} & (36 \%) \\
\end{array}$ & $\begin{array}{l}15^{\mathrm{b}^{*}}(37 \%) \\
26^{\mathrm{b}^{*}}(63 \%) \\
\end{array}$ \\
\hline \multicolumn{4}{|c|}{ Stage } \\
\hline $\begin{array}{l}\mathrm{IE} \\
\mathrm{IIE} \\
\mathrm{IIIE} \\
\mathrm{IVE}\end{array}$ & $\begin{array}{l}25(83 \%) \\
4(14 \%) \\
1(3 \%) \\
0(0 \%)\end{array}$ & $\begin{array}{l}22(61 \%) \\
8(22 \%) \\
5(14 \%) \\
1(3 \%)\end{array}$ & \begin{tabular}{|l|}
24 a\# $(59 \%)$ \\
$13(32 \%)$ \\
$1(2 \%)$ \\
$3(7 \%)$
\end{tabular} \\
\hline
\end{tabular}

a- Low a grade MALT vs. MALT BLBCL, b- Low-grade MALT vs. De Novo BLBCL, c- MALT BLBCL vs. De Novo BLBCL and * $P<0.001, \$ \mathrm{P}<0.005, \# \mathrm{P}<0.05$

Table 1: Clinicopathological characteristic of gastric lymphoma patients.

\begin{tabular}{|l|l|l|l|}
\hline & $\begin{array}{l}\text { MSI before } \\
\text { HP eradication }\end{array}$ & $\begin{array}{l}\text { MSI after } \\
\text { HP eradication }\end{array}$ & $p$ \\
\hline Low grade MALT & $6 / 30(20 \%)$ & $0 / 30(0 \%)$ & $<0.001$ \\
\hline MALTDLBCL & $16 / 36^{\text {a\# }}(44 \%)$ & $2 / 36(6 \%)$ & $<0.001$ \\
\hline De novo DLBCL & $15 / 41^{\text {b\# }}(36 \%)$ & $5 / 41(12 \%)$ & $<0.01$ \\
\hline
\end{tabular}

a- Low a grade MALT vs. MALT BLBCL b- Low-grade MALT vs. De Novo BLBCL C- MALT BLBCL vs. De Novo BLBCL

${ }^{*} \mathrm{P}<0.001, \$ \mathrm{P}<0.01, \# \mathrm{P}<0.05$

Table 2: Incidence of $\mathrm{MSI}$ in gastric lymphoma patients before and after helicobacter eradication.

\begin{tabular}{|c|c|c|c|}
\hline & Low grade MALT & MALTDLBCL & De Novo DLBCL \\
\hline \multicolumn{4}{|c|}{ Post HP eradication } \\
\hline $\begin{array}{l}\text { CR } \\
\text { NR }\end{array}$ & \begin{tabular}{|l|}
$27 / 30(90 \%)$ \\
$3 / 30(10 \%)$
\end{tabular} & $\begin{array}{l}25 / 36{ }^{\text {a\# }}(69 \%) \\
11 / 36(31 \%)\end{array}$ & $\begin{array}{l}3 / 411^{b^{*}}(7 \%) \\
38 / 41(83 \%)\end{array}$ \\
\hline \multicolumn{4}{|l|}{ Depth } \\
\hline $\begin{array}{l}\text { SM or above } \\
\text { MP or Beyond }\end{array}$ & $\begin{array}{l}27 / 27(100 \%) \\
0 / 3(0 \%)\end{array}$ & $\begin{array}{l}23 / 23^{a^{*}}(100 \%) \\
2 / 13(15 \%)\end{array}$ & $\begin{array}{l}3 / 15^{b^{*}}(20 \%) \\
0 / 26(0 \%)\end{array}$ \\
\hline \multicolumn{4}{|l|}{ Chemotherapy } \\
\hline $\begin{array}{l}\text { CR } \\
\text { NR }\end{array}$ & \begin{tabular}{|l|}
$3 / 3(100 \%)$ \\
$0 / 3(0 \%)$
\end{tabular} & \begin{tabular}{|l|}
$16 / 16(100 \%)$ \\
$0 / 11(0 \%)$
\end{tabular} & \begin{tabular}{|l|}
$38 / 38(100 \%)$ \\
$0 / 34(0 \%)$
\end{tabular} \\
\hline
\end{tabular}

$\mathrm{HP}=$ helicobacter pylori, $\mathrm{SM}=$ submucosa, $\mathrm{Mp}=$ muscularis propria, $\mathrm{CR}=$ complete remission, $\mathrm{PR}$ partial remission, $\mathrm{NR}=$ no response

a- Low a grade MALT vs. MALT BLBCL, b- Low-grade MALT vs. De Novo BLBCL c- MALT BLBCL vs. De Novo BLBCL and * $P<0.001, \$ P<0.01$, \# $P<0.05$

Table 3: Result of response rate $\mathrm{y}$ in primary gastric lymphoma patients to Helicobacter Pylori treatment.

In patients with low-grade MALT lymphoma, the age ranged between 38 and 85 years (mean 59 years), in those with high-grade DLBCL (MALTDLBCL) lymphomas the age range was 45-77 years (mean 60.7 years), and those with de novo DLBCL the range was between 44 and 85 years (mean 67.4 years). A higher mean value of age was found in patients with de novo DLBCL. This finding was found to be statistically significant at analysis compared to low grade cases $(\mathrm{P}<0.05)$. There was a predominance of females in the low grade MALT lymphoma group (male/female ratio, 1:2), whereas males predominated among patients with high-grade DLBCL lymphoma (male/female ratio $2.5: 1$ ) and the de novo DLBCL patients (male/ female ratio 3:1). The sex ratio of MALT lymphoma patients was statistically significantly different when compared to MALTDLBCL lymphoma patients and de novo DLBCL lymphoma $(\mathrm{P}<0.001, \mathrm{P} 0.005)$ respectively. Analysis of tumor site and endoscopic features showed no significant difference among the 3 groups.

Histopathological examination of the biopsy specimens showed that the disease was confined to the mucosal and submucosal layers in 27 out of 30 patients $(90 \%)$ in the low-grade MALT lymphomas, 23 out of $36(64 \%)$ in MALTDLBCL lymphomas and 15 out of $41(37 \%)$ in de novo DLBCL groups, the incidence was statistically significantly higher in low grade MALT lymphoma in comparison to MALTDLBCL and those with de novo DLBCL $(\mathrm{P}<0.05, \mathrm{p}<0.001$ respectively). In contrast, the lymphoma cells invaded the muscular layer or beyond in 26 of $41(63 \%)$ of de novo DLBCL cases. The depth of tumor invasion was significantly greater in de novo DLBCL patients than in those with low grade MALT and MALTDLBCL lymphoma patients $(\mathrm{P}<0.001$, $\mathrm{P}<0.05$ respectively). Table 1 shows the demographic + Clinicopathological data of the studied patients (Table 1).

\section{The clinic-pathological data of primary gastric lymphoma patients (Table1)}

Analysis of Micro satellite Instability (MSI): The result of MSI before and after helicobacter eradication therapy in all groups of primary gastric lymphoma (Table 2): The incidence of MSI at presentation in low grade MALT was $6 / 30$ patients $(20 \%)$, in patients with MALTDLBCL it was found in $16 / 36$ patients $(44 \%)$ and in those de novo DLBCL it was $15 / 41$ patients $(37 \%)$. The frequency of MSI in MALTDLBCL and de novo DLBCL was statistically significantly higher than in low grade MALT $(\mathrm{P}<0.05)$.

Reassessment of presence of MSI after helicobacter Pylori eradication therapy showed significant decrease of its incidence in all groups. In patients with low grade MALT the incidence of MSI decreased from $(6 / 30$ to $0 / 30(P<0.001)$, All these patients achieved complete remission after helicobacter eradication. In patients with MALTDLBCL the frequency of MSI decreased from (16/36 to 2/36, $\mathrm{P}<0.001$ ), all 14 patients who achieved complete remission had no evidence of MSI and the two patients were non responders to helicobacter eradication. In those with de novo DLBCL the frequency of MSI decreased from $(15 / 41$ to $5 / 41, P<0.01)$, three patients of them achieved complete remission after helicobacter eradication therapy; while remaining seven patients showed complete remission post chemotherapy.

In analysis of microsatellite marker, there was statistically significant increase incidence in D5S346, D9S171 and D17S250 in patients with de novo DLBCL and MALTDLBCL in comparison to those with low grade MALT. In D3S1530 it was significantly higher in MALTDLBCL in comparison to low grade MALT (Figure 2).

\section{Tumor response}

Assessment of response at 6 weeks post completing anti-HP treatment course showed $90 \%$ complete histological remission (CR) in patients with low-grade MALT disease (27/30 patients), the remaining 3 patients did not respond to eradication therapy. In MALTDLBCL group the complete response rate (CR) was achieved in 25/36 patients $(69 \%)$ and 11 patients did not respond to Helicobacter pylori eradication. In the de novo DLBCL 3/41 (7\%) responded to helicobacter eradication while the majority $93 \%$ (38 patients) not respond to Helicobacter pylori eradication. The response to Helicobacter pylori treatment was significantly higher in Low grade 


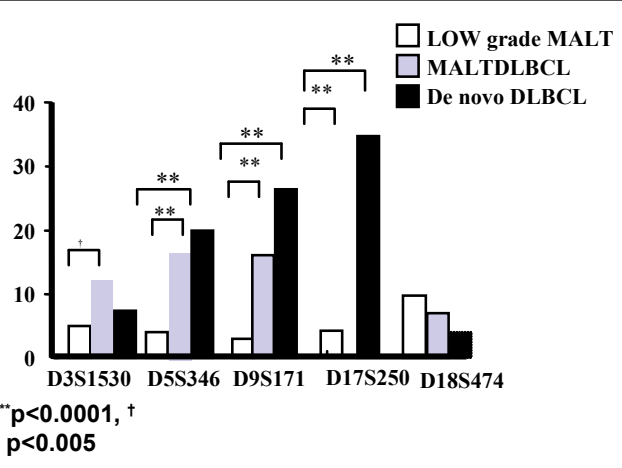

Figure 2: The frequency of Microsatellite instability (MSI) in differen microsatellite markers was detected in primary gastric lymphoma patients.

MALT lymphoma group compared to MALTDLBCL and de novo DLBCL patients $(\mathrm{p}<0.05, \mathrm{p}<0.001)$ respectively.

The relation of response rate to Helicobacter Pylori eradication therapy to degree of mucosal invasion was another interesting finding. In the low grade MALT type all complete responders had disease limited to mucosa and submucosa only, while in MALTDLBCL two patients of the complete responders had disease invasion to muscularis propria. In de novo DLBCL, the only 3 patients who responded to Helicobacter pylori eradication had the invasion depth limited to mucosa and submucosa only.

Response of primary gastric lymphoma patients post helicobacter pylori eradication (Table 3 )

Response of primary gastric lymphoma patients to chemotherapy (Table 3): Patients who did not achieve CR after helicobacter eradication therapy referred to systemic chemotherapy (Anthracyclin based chemotherapy). 3 patients of Low grade MALT received chemotherapy and achieved CR after 4 cycle of chemotherapy. 11 patients of MALTDLBCL lymphoma received CHOP and achieved CR post chemotherapy, 9 of them after 3 cycles and others 2 patients after 6 cycles. 38 patients of de novo DLBCL received anthracyclinbased chemotherapy (CHOP), 32 patients achieved CR after 3 cycle and others 6 after 6 cycles of chemotherapy.

\section{Discussion}

To the best of our knowledge, this is the first study evaluating the alteration in MSI level in primary gastric lymphoma before and after Helicobacter Pylori eradication with long term follow up (1999 -2004) We clearly found 1) The incidence of MSI at diagnosis significantly increases from low grade MALT gastric lymphoma to DLBCL gastric lymphoma, 2) The incidence of MSI significantly decrease post helicobacter pylori eradication therapy and is significantly correlated with histological remission, 3) Chemotherapy in cases of failure to respond to anti HP therapy contributed to complete response in DeNovo DLBCL gastric lymphoma.

MSI is a mutation phenotype that occurs through defect in DNA mismatch repair system and contributes in cancer development [28]. Our results showed that incidence of MSI significantly increases as the histological subtype progress from low grade gastric MALT to MALTDLBCL and DLBCL which express that MSI plays an important contributory role in transformation to high grade disease. This finding supports previous reports about the role of MSI in lymphogenesis $[3,18,19,20]$ There are a few explanations about the difference in incidence of MSI between our study and these reports. First, the choice of genetic loci for MSI analysis, we analyzed markers adjacent to chromosomal loci that are involved in lymphomas, 'Real Common Target genes theory' $[3,18]$. Second, method of analysis micro satellite instability, our analysis was based on gel electrophoresis which is the most accurate method $[3,29]$. The incidence of instability in locus differs in studied subjects depending on the genetic background of people and geographic regions $[30,31]$.

Many studies reported that the change in the molecular behavior in patients post eradication of Helicobacter pylori have an important impact in decreased incidence of carcinogensis [32-35]. Our result showed significant change in molecular behavior by reversion in the DNA damage (MSI) post Helicobacter Pylori eradication and that associated with histological remission of primary gastric lymphoma, which clarify the importance of the role of helicobacter eradication treatment not only in low grade MALT lymphoma but also in DLBCL gastric lymphoma (with and without MALT components). Eradication of helicobacter pylori release cell from inflammatory toxic effect and restore normal function expression of the cell [25].

Several studies have shown that Helicobacter pylori eradication results in durable histological complete remission in patients with gastric DLBCL (with and without MALT Component) $[9-15,16]$. In agreement with previous reports, our result showed the complete response rate (CR) in MALTDLBCL to helicobacter eradication therapy was $69 \%$, and in de novo DLBCL was $7 \%$. No significance difference among all group in overall survival after helicobacter eradication support the previous conclusion that loss of helicobacter dependence and high grade transformation are two separate events [16,38].

Another interesting finding was that complete response to helicobacter eradication therapy significantly correlated with the depth of tumor invasion depth in all histological subtypes of gastric lymphoma as previously reported $[9,16,35,36]$.

Other studies reported the efficacy of (chemotherapy) as compared to surgery in treatment of gastric lymphoma specially DLBCL gastric lymphoma $[35,37,39]$. In our study we clarify that patients who did not achieve CR post Helicobacter eradication had a very good response to chemotherapy and achieved very rapid CR response with no significance difference in overall survival between MALT and non MALT gastric lymphoma, this phenomenon can be explained by the fact that eradication of helicobacter retain the biological behavior of cells (e.g., responsiveness to lymphocyte-activating cytokines such as tumor necrosis factor $\alpha$, interleukin [IL]- which may be contributed to excellent result chemotherapy $[13,37]$ and also with correction of genetic errors on cell such as microsatellite instability as we may be also contribute for good response and rapid remission rate by prevention of DNA error replication which lead to cut the antigenic pathway stimulation of gastric lymphoma.

In conclusion, microsatellite insatiability (MSI) plays an important role in development of primary gastric lymphoma mainly in DLBCL types. Our result confirmed the role of Helicobacter pylori eradication in controlling primary gastric lymphoma and its effect in correction of MSI. We recommend addition of Helicobacter Pylori eradicating therapy to all newly diagnosed cases of HP associated gastric lymphomas and especially to DLBCL type.

\section{References}

1. Groves FD, Linet MS, Travis LB, Devesa SS (2000) Cancer surveillance series non-Hodgkin's lymphoma incidence by histologic subtype in the United States from 1978 through 1995. J Natl Cancer Inst 92: 1240-1251.

2. Ferrucci PF, Zucca E (2007) Primary gastric lymphoma pathogenesis and treatment: what has changed over the past 10 years? Br J Haematol 136: 521 538 
Citation: Ezz Eldin AM, Alkareemy ER, Zedan A, Abdel Warith A, Zaky AH, et al. (2010) The Role of Anti-Helicobacter Pylori Therapy in Remission Induction of Primary Gastric Lymphoma by Analysis of Microsatellite Instability. J Carcinogene Mutagene 1:107. doi:10.4172/2157-2518.1000107

Page 5 of 5

3. Starostik P, Greiner A, Schwarz S, Patzner J, Schultz A, et al. (2000) The role of microsatellite instability in gastric low- and high-grade lymphoma development. Am J Pathol 157: 1129-1136.

4. Harris NL, Jaffe Es, Diebold J, Fladrin G, Muller-Hermelink HK, et al. (1999) The World Health organization classification of neoplastic diseases of hematopoietic and lymphoid tissues: report of clical advisory committee meeting-Airlie house, Virginia, November 1997. J Clin Oncol 10: 1419-1432.

5. Hussell T, Isaacson PG, Crabtree JE, Spencer J (1993) The response of cell from low-grade B-cell gastric lymphomas of mucosa associated lymphoid tissue to Helicobacter pylori. Lancet 342: 571-574.

6. Ferreri AJ, Montalbán C (2007) Primary diffuse large B-cell lymphoma of the stomach. Crit Rev Oncol Hematol 63: 65-71.

7. Ferreri AJ, Freschi M, Dell'Oro S, Viale E, Villa E, et al. (2001) prognostic significance of histopathologic recognition of low and high grade component in stage I-II B-cell gastric lymphoma. Am J Surg Pathol 25: 95-102.

8. Santacroce L, Cagiano R, Del Prete R, Bottalico L, Sabatini R, et al. (2008) H pylori infection and gastric MALTomas: an up- to-date and therapy highlight. Clin Ter 159: 457-462.

9. Rudolph B, Bayerdörffer E, Ritter M, Müller S, Thiede C, et al. (1997) Is the polymerase chain reaction or cure of Helicobacter pylori infection of help in the differential diagnosis of early gastric mucosa-associated lymphatic tissue lymphoma? J Clin Oncol 15: 1104-1109.

10. Seymour JF, Anderson RP, Bhathal PS (1997) Regression of gastric lymphoma with therapy for Helicobacter pylori infection. Ann Intern Med 127: 247.

11. Ng WW, Lam CP, Chau WK, Fen-Yau Li A, Huang CC, et al. (2000) Regression of high-grade gastric mucosa-associated lymphoid tissue lymphoma with Helicobacter pylori after triple antibiotic therapy. Gastrointest Endosc 51: 93-96.

12. Morgner A, Miehlke S, Fischbach $W$, Schmitt W, Müller-Hermelink $H$, et al. (2001) Complete remission of primary high-grade B-cell gastric lymphoma after cure of Helicobacter pylori infection. J Clin Oncol 19: 2041-2048.

13. Sugimoto M, Kajimura M, Sato $Y$, Hanai H, Kaneko E, et al. (2001) Regression of primary gastric diffuse large B-cell lymphoma after eradication of Helicobacter pylori. Gastrointest Endosc 54: 643-645.

14. Timm S, Sailer M, Fuchs KH, Greiner A (2001) First successful treatment of a primary high-grade gastric MALT lymphoma by eradication therapy for Helicobacter pylori. Gastroenterology 121: 1025-1026.

15. Montalban C, Santon A, Boixeda D, Bellas C (2001) Regression of gastric highgrade mucosa associated lymphoid tissue (MALT) lymphoma after Helicobacter pylori eradication. Gut 49: 584-587.

16. Chen LT, Lin JT, Shyu RY, Jan CM, Chen CL, et al. (2001) Prospective study of Helicobacter pylori eradication therapy in stage IE high-grade mucosaassociated lymphoid tissue lymphoma of the stomach. J Clin Oncol 19: 42454251.

17. Skacel M, Paris PL, Pettay JD, Tsiftsakis EK, Tubbs RR, et al. (2002) Diffuse large B-cell lymphoma of the stomach: assessment of micro satellite instability, allelic imbalance and trisomy of chromosomes 3,12 and 18. Diagn Mol Patho 11: $75-82$.

18. Niv E, Bomstein Y, Bernheim J, Lishner M (2004) Microsatellite instability in gastric MALT Iymphoma. Mod Pathol 17: 1407-141.

19. Chong JM, Fukayama M, Hayashi Y, Hishima T, Funata N, et al. (1997) Micro satellite instability and loss of heterozygosity in gastric lymphoma. Lab Invest 77: 639-645.

20. Peng H, Chen G, Du M, Singh N, Isaacson PG, et al. (1996) Replication error phenotype and p53 gene mutation in lymphomas of mucosa-associated lymphoid tissue. Am J Pathol 148: 643-648.

21. Xu WS, Chan AC, Liang R, Srivastava G (1998) No evidence of replication error phenotype in primary gastric lymphoma of mucosa-associated lymphoid tissue. Int J Cancer 76: 635-638.
22. Musshoff K (1977) Clinical staging classification of non-Hodgkin's lymphomas. Strahlentherapie 153: 218-221.

23. Wotherspoon AC, Doglioni C, Diss TC, Pan L, Moschini A, et al. (1993) Regression of primary low-grade B-cell gastric lymphoma of mucosaassociated lymphoid tissue type after eradication of Helicobacter pylori. Lancet 342: 575-577.

24. Simone NL, Bonner RF, Gillespie JW, Emmert-Buck MR, Liotta LA (1998) Laser captures microdissection: opening the microscopic frontier to molecular analysis. Trends Genet 14: 272-276.

25. Tanaka A, Watari J, Tanabe H, Maemoto A, Fujiya M, et al. (2006) Effect of eradication of Helicobacter pylori on genetic instabilities in gastric intestinal metaplasia. Aliment Pharmacol Ther 24: 194-202.

26. Boland CR, Thibodeau SN, Hamilton SR, Sidransky D, Eshleman JR, et al. (1998) A National Cancer Institute Workshop on micro satellite instability for cancer detection and familial predisposition: development of international criteria for the determination of microsatellite instability in colorectal cancer. Cancer Res 58: 5248-5257.

27. Dietmaier W, Wallinger S, Bocker T, Kullmann F, Fishel R, et al. (1997) Diagnostic microsatellite instability: definition and correlation with mismatch repair protein expression. Cancer Res 57: 4749-4756.

28. Loeb LA (1994) Microsatellite instability: marker of mutator phenotype in cancer. Cancer Res 54: 5059-5063.

29. Tokunaga E, Oki E, Oda S, Kataoka A, Kitamura K, et al. (2000) Frequency of micro satellite instability in breast cancer determined by high-resolution fluorescent microsatellite analysis. Oncology 59: 44-49.

30. Rugge M, Bersani G, Bertorelle R, Pennelli G, Russo VM, et al. (2005) Microsatellite instability and gastric non-invasive neoplasia in high risk population in Cesena, Italy. J Clin Pathol 58: 805-810.

31. Sepulveda AR, Santos AC, Yamaoka Y, Wu L, Gutierrez O, et al. (1999) Marked differences in the frequency of microsatellite instability in gastric cancer from different countries. Am J Gastroenterol 94: 3034-3038.

32. Hibi K, Mitomi H, Koizumi W, Tanabe S, Saigenji K, et al. (1997) Enhanced cellular proliferation and P53 accumulation in gastric mucosa chronically infected with Helicobacter Pylori. Am J Clin pathology 108: 26-34.

33. Jones NL, Shannon PT, Cutz E, Yeger H, Sherman PM (1997) Increased in proliferation and apoptosis of gastric epithelial cells on the natural history of helicobacter Pylori infection. Am J Pathol 151: 1695-1703.

34. Hiyama T, Haruma K, Kitadai Y, Masuda H, Miyamoto M, et al. (2002) K-ras mutation in Helicobacter Pylori associated chronic gastritis in patients with and without gastric cancer. Int J cancer 97: 562-566.

35. Miyamoto S, Okamoto R, Maeda Y, Hishima T, Sasaki T (2008) Two cases of stomach primary diffuse large $B$ cell lymphoma remitted by helicobacter pylori eradication therapy. Gan To Kogaku Ryoho 35: 2437-2440.

36. Fischbach W, Goebeler-Kolve ME, Dragosics B, Greiner A, Stolte M (2004) Long outcome of patients with gastric marginal zone B cell lymphoma of mucosa associated lymphoid tissue (MALT) following exculsive Helicobacter eradication pylori eradication therapy: experience from large prospective series. Gut 53: 34-37.

37. Raderer M, Chott A, Drach J, Montalban C, Dragosics B, et al. (2002) Chemotherapy for management of localised high-grade gastric B-cell lymphoma: how much is necessary? Ann Oncol 13: 1094-1098.

38. Raderer M, Valencak J, Osterreicher C, Drach J, Hejna M, et al. (2000) Chemotherapy for the treatment of patients with primary high grade gastric B-cell lymphoma of modified Ann Arbor Stages IE and IIE. Cancer 88: 19791985.

39. Koch P, del Valle F, Berdel WE, Willich NA, Reers B, et al. (2001) German Multicenter Study Group. J Clin Oncol 193:874-883. 